\title{
THE IDEAL DISTRIBUTION OF FARMERS: EXPLAINING THE EURO-AMERICAN SETTLEMENT OF UTAH
}

\author{
Peter M. Yaworsky and Brian F. Codding
}

\begin{abstract}
Explaining how and why populations settle a new landscape is central to many questions in American archaeology. Recent advances in settlement research have adopted predictions from the Ideal Free Distribution model (IFD). While tests of IFD predictions to date rely either on archaeologically derived coarse-grained diachronic data or ethnographically derived finegrained synchronic data, here we provide the first test using historically derived data that is both fine-grained and diachronic. Fine-grain diachronic data allow us to test model predictions at a temporal scale in line with human settlement decisions and to validate proxies for application in archaeological contexts. To test model predictions pertaining to the relationship between population density and habitat quality, we use data from the historical settlement of Utah. The results demonstrate a negative relationship between population density and the quality of habitats occupied. These results are consistent with IFD predictions, suggesting that Euro-American settlement of Utah resulted from individuals attempting to maximize individual returns via agricultural productivity. Our results provide a quantitative and testable explanation for population dispersion over time and explain the spatial distribution of population density today. The results support predictions derived from a general theory of behavior, providing an explanatory framework for colonization events worldwide.
\end{abstract}

Explicar cómo y por qué las poblaciones se instalan en un nuevo lugar es fundamental para muchas preguntas en la arqueología americana. Los avances recientes en la investigación de asentamientos han adoptado las predicciones del modelo de Distribución Libre Ideal (DLI). Mientras que las pruebas de las predicciones de DLI hasta la fecha se basan, ya sea en información diacrónica impresisa, que nos llega a través de los arqueólogos, o de información sincrónica precisa de etnografía. Aquí proporcionamos la primera prueba utilizando datos históricos derivados que es a la vez precisa y diacrónica. Los datos diacrónicos precisos nos permiten, evaluar las predicciones a largo plazo del modelo, en una escala temporal en línea con las decisiones de los asentamientos humanos, y también validar los proxies que se pueden aplicar en contextos arqueológicos. Para poner a prueba las predicciones del modelo, perteneciente a la relación entre la densidad de la población y la calidad del habitat, usamos los datos de los asentamientos históricos en Utah. Los resultados demuestran una relación negativa entre la densidad de la población y la calidad de las habitats ocupados. Los resultados son consistentes con las predicciones de DLI, lo que sugiere que los primeros modelos de asentamiento euro-americanos en Utah fueron el resultado de personas que trataron de maximizar la eficiencia de la agricultura. Los metodos utilizados aquí proporcionan una explicación cuantitativa y comprobable para la dispersión de la gente a través del tiempo y explica las diferencias en la distribución especial de la densidad poblacional hoy en dia. Estos resultados apoyan las predicciones derivadas de una teoría general de comportamiento, proporcionando una explicación para eventos de colonización en todo el mundo.

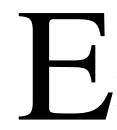
xplaining prehistoric colonization and migration events is a central research theme in American archaeology (e.g., Bell et al. 2015; Schwindt et al. 2016; Smallwood 2012). Recent advances framed by behavioral ecology have drawn on the Ideal Free Distribution model (IFD; Fretwell and Lucas 1969) to explain population movements across continents
(Codding and Jones 2013; Hildebrandt et al. 2016; O'Connell and Allen 2012; Prufer et al. 2017) and islands (Giovas and Fitzpatrick 2014; Jazwa et al. 2013; Jazwa et al. 2016; Kennett 2005; Winterhalder et al. 2010; see Codding and Bird 2015 for review). The IFD model makes the simple prediction that if individuals are free to choose where to make a living, they

Peter M. Yaworsky and Brian F. Codding — Department of Anthropology and Archaeological Center, University of Utah, Salt Lake City, UT 84112, USA (p.yaworsky@utah.edu, corresponding author; brian.codding@ anthro.

utah.edu)

American Antiquity 83(1), 2018, pp. 75-90

Copyright (C) 2017 by the Society for American Archaeology

doi:10.1017/aaq.2017.46 
should distribute themselves across a varying landscape proportional to the suitability of the local environment. The result is an "ideal" settlement pattern in which more people competing in higher-quality areas and fewer people competing in lower-quality areas result in the same rate of economic yield per individual.

An advantage of the IFD model is that the basic framework is structured by individual decisions, but results in aggregate patterns that can be measured at scales amenable to the archaeological record. However, one problem with archaeological applications of the IFD model is that the aggregate outcome is imprecisely measured at coarse-grained scales without linking the individual decisions to broad patterns. While ethnographic studies show that the IFD model can predict short-term settlement patterns (Moritz et al. 2014; Moritz et al. 2015), there are no empirical evaluations linking high-resolution data on the factors that structure settlement decisions to the resulting long-term, aggregate outcomes. The field needs such a test to validate assumptions in archaeological applications and relative proxies used to measure human populations and habitat suitability. Unlike archaeological and ethnographic data, historical data provide an ideal intermediate level of resolution and temporal scale. While such data are rarely used to evaluate predictions from behavioral ecological models, the few cases that exist help validate model assumptions and predictions (e.g., Glover 2009), while also providing novel insights to interpretations of the recent past (Galle 2010; Neiman 2008).

To further the study of population movements, we provide a novel test of IFD predictions with annual-scale diachronic data recording the settlement decisions of a natural fertility, agricultural population in Utah. The region was originally occupied by Native Americans, including the Ute, Shoshone, Southern Paiute, and Navajo, but beginning in the mid-nineteenth century, the region was inundated by homogeneous, smallscale, family-based farming communities associated with the Church of Latter-day Saints (Brown et al. 1994; Jackson 1978; Malouf and Findlay 1986; Ricks 1930). Although historians have offered many proximate (sensu Tinbergen 1963) explanations for this settle- ment (Abruzzi 1987; Jackson 1978; Ricks 1930; Scarlett 2006; Scarlett et al. 2007; Smith 2015), here we provide the first ultimate explanation informed by evolutionary theory. Based on the IFD model, we expect that individuals will initially settle in high-productivity environments, only moving into lower-quality areas as a result of demographic competition in the most suitable locations (Fretwell and Lucas 1969). As such, if Utah's settler-colonists sought to maximize agricultural productivity, then we expect to see a negative relationship between population density and the overall agricultural suitability of occupied habitats. To test this prediction, we develop novel proxies of agricultural suitability and evaluate how the suitability of occupied environments varies with quantitative demographic data. Before discussing the methods and results, we first present the details of the IFD model and the historical context for this colonization event.

\section{The Ideal Free Distribution Model}

The IFD model was developed by Fretwell and Lucas (1969) to explain dispersal and territorial patterns relative to environmental variation and demographic competition. The basic model assumes that habitat suitability varies across the landscape, that individuals have perfect knowledge of their environment and are free (i.e., not excluded by competitors) to settle where they choose, and that habitat suitability is characterized by negative density dependence (meaning the suitability of a habitat declines as a function of increasing competition). The basic predictions for a simple, two-habitat scenario appear in Figure 1, using equation 1 from Greene and Stamps (2001). If settlement decisions are structured by the goal of maximizing suitability (for example, per capita energetic return rates), then the first individual in an area should occupy the most suitable habitat (H1). As populations increase through migration or reproduction, the suitability of the best habitat declines as a result of increasing intra-habitat competition between conspecifics. When suitability declines in $\mathrm{H} 1$ to the maximum suitability of the second most suitable habitat (H2), incoming individuals should distribute themselves between the first and second most suitable habitats ( $\mathrm{H} 1$ and $\mathrm{H} 2)$. The 


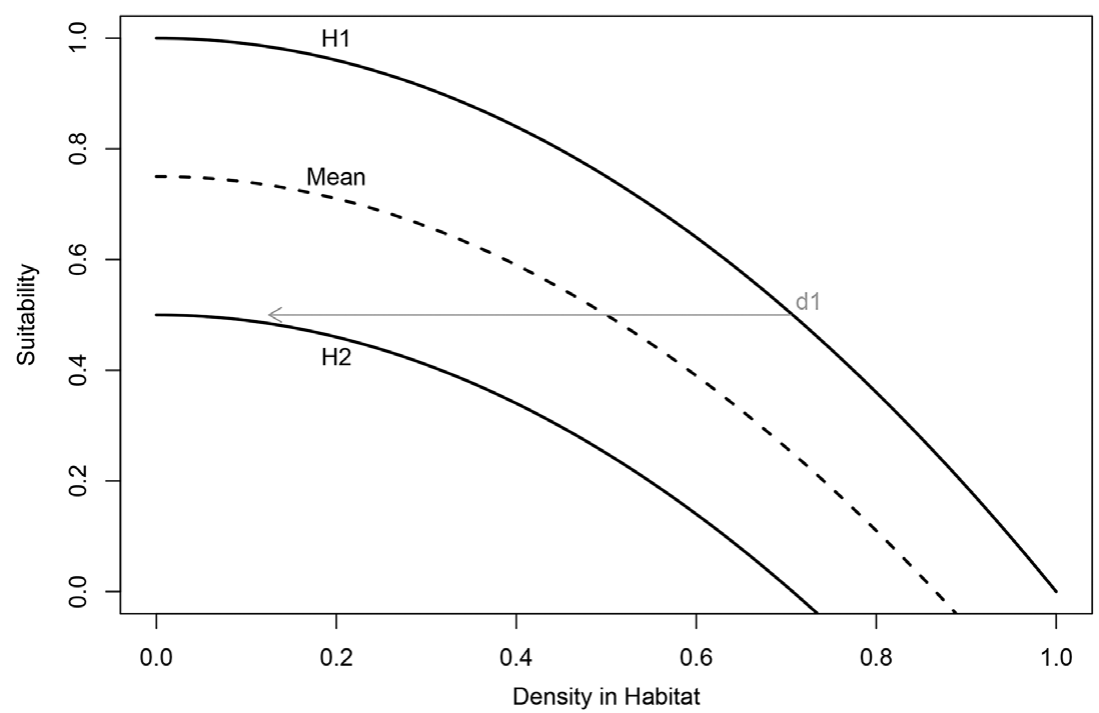

Figure 1. Graphical representation of the basic Ideal Free Distribution model in a simple two-habitat scenario (following Greene and Stamps 2001 eq. 1). Populations should occupy only the most suitable habitat (H1) until the point (d1) at which demographic pressure lowers the per capita gains to be equal to what individuals would gain at lower densities in the next most suitable habitat (H2). The mean suitability of occupied habitats represents the aggregate outcomes of these individual settlement decisions.

result is an "ideal" distribution of individuals wherein all individuals receive the same rate of resource acquisition from the environment. If growth continues, populations will continue to expand in both habitats, further decreasing habitat suitability. The overall suitability experienced by individuals across all occupied habitats is then the average suitability of all occupied habitats, which declines in suitability with increasing populations (Figure 1, mean value).

Departures from the standard IFD model predictions often take two forms. The first, known as Allee's Principle, involves a violation of strict negative density dependence, wherein the suitability of a habitat initially increases due to the benefits individuals receive from more individuals interacting in that habitat (Fretwell and Lucas 1969). In this case, benefits can range from reducing the burden of vigilance to making resource acquisition more efficient through cooperative production or habitat modification, which will increase overall habitat suitability, and may cause individuals to stay longer in the most suitable habitats than would be predicted by the standard IFD model. The second, known as the Ideal Despotic Distribution (IDD) model, involves the violation of the "free" assumption, wherein some individuals or groups may exclude others from their optimal habitat through territorial behavior (Fretwell and Lucas 1969). Such exclusionary behaviors may lead individuals to settle in lower suitability habitats earlier than predicted by the IFD model (for a recent archaeological application, see Prufer et al. 2017). Recent modeling also suggests that human despotism may have the opposite effect if a despot benefits from having more subservient individuals within their territory (Bell and Winterhalder 2014).

\section{The Context}

The first Euro-American settler-colonists of Utah were members of the Church of Jesus Christ of Latter-day Saints (LDS Church), also known as Mormons. Initial settler-colonists traveled 1,031 miles from Winter Quarters, Iowa, to the Great Salt Lake Valley, leaving the United States and entering what was then Mexico. Arriving at the Great Salt Lake Valley on July 22, 1847, they established a settlement at the canyon mouth of City Creek in what would become downtown Salt Lake City, and began diverting water from the 
small streams in the area to irrigate rye and other grain crops (Arrington and May 1975; Brown et al. 1994; Ricks 1930). Populations grew through continued immigration and reproduction; by 1870 , the Salt Lake Valley was home to 18,000 residents. Continued population growth led newcomers to establish more distant settlements beyond the Salt Lake Valley (Brown et al. 1994; Ricks 1930; Scarlett 2006; Scarlett et al. 2007). The new settlements were designed to be self-sufficient farming communities that adopted both irrigated and non-irrigated farming techniques (Abruzzi 1987; Arrington and May 1975; Ricks 1930). The LDS Church, most notably its leader Brigham Young, was particularly involved in the directed settlement of the region, with the goal of establishing a Mormon "State of Deseret" (Anderson 1942; Arrington and May 1975; Brown et al. 1994; Jackson 1978; Meinig 1965; Ricks 1930). While his vision never came to fruition, his attempts at establishing a broad distribution of Mormons throughout the West are seen in the historical record. Young sent scouting parties throughout the West in an attempt to secure strategic and productive locations for dispersing settler-colonists. Historical documents record the settlement of key areas identified for their agricultural potential for incoming settlercolonists (i.e., Brigham City, founded 1851; Manti, 1849; and Saint George, 1861; see Ricks 1930). The extent of the LDS Church's involvement in settlement appears to be limited to the initial decades of settlement, ending prior to 1880 as Mormon autonomy in the region declined due to federal oversight (Brown et al. 1994; Lindell 2011; Meinig 1965; Ricks 1930).

The Mormon settlers were the first EuroAmerican group intent on permanently settling the region (Cuch 2000; Lindell 2011; Malouf and Findlay 1986). After the Mormons migrated west, their perceptions of Native Americans quickly changed from potential converts to competitors, scapegoats, and political pawns, with antagonistic interactions ranging from passive displacement to violent conflict (Blackhawk 2006; Cuch 2000; Lindell 2011). While the resulting conflicts decimated local Native Americans and their way of life, Euro-American settlement seems to have been only minimally impeded (Blackhawk 2006; Farmer 2008; Lin- dell 2011). Some argue that this asymmetrical result was in part due to the more intensive economy, lower mobility, stronger conceptions of ownership, and higher rates of population growth of the settler-colonists (Allen 1991; Smaby 1975). Regardless, historians report that EuroAmericans displaced local Native Americans early in the process of colonization (Blackhawk 2006; Cuch 2000; Farmer 2008; Lindell 2011; for a detailed discussion on the history of MormonNative American interactions, see Lindel [2011] and Cuch [2000]).

There are 347 Euro-American settlements (including those abandoned) in Utah established between 1847 and 2013 (Barton 1998; Carr 1986; Thompson 1982; Utah Writers' Project 1940). Historians largely attribute colonization decisions to direction of the LDS Church (Abruzzi 1987; Jackson 1978; Ricks 1930; Smith 2015). Historical researchers assert that dispersion and settlement were the products of environmental perceptions of the group's leaders, whom LDS members perceived as divine, and who had centralized control over the population on matters ranging from ideology to economy (Abruzzi 1987; Jackson 1978; Ricks 1930; Smith 2015). Although the settlement of Utah is often framed within this context of religious zeal, here we test the simpler prediction that it was guided by economic rationale.

\section{Data and Methods}

To test the IFD model prediction that population density and habitat suitability negatively covary, we combine settlement and population data with estimates of habitat suitability. The settlement data and population data used below are available on the Harvard Dataverse (Yaworsky 2017).

\section{Settlement Data}

Settlement Sample. We select 100 settlements at random from the 347 Utah settlements established between 1847 and 2013 (Barton 1998; Carr 1986; Thompson 1982; Utah Writers' Project 1940). From the sample settlements, we exclude 16 due to settlement after 1950 ( $n$ $=2)$, conflicting settlement dates $(n=1)$, or lack of complete data needed for the analysis $(n=13)$. Settlement dates (interquartile range 
(a)

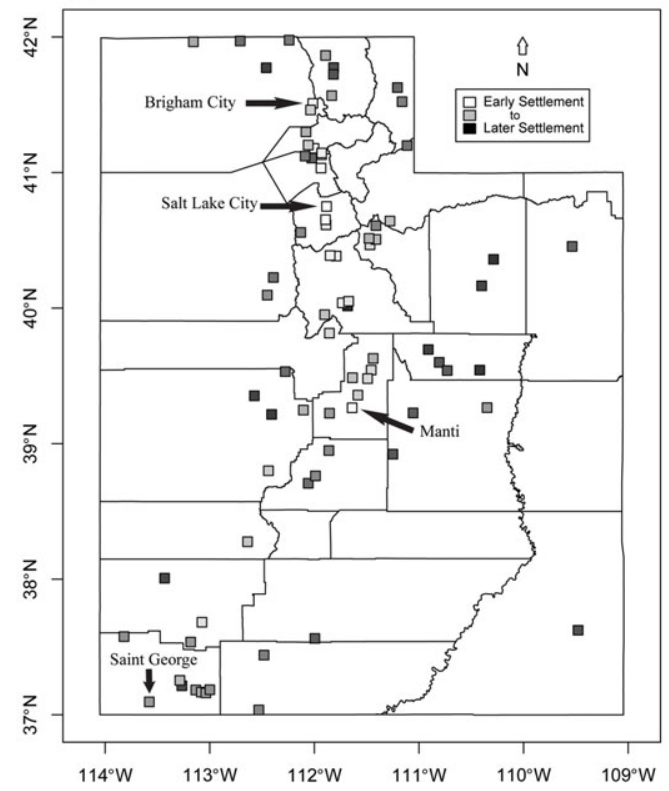

(b)

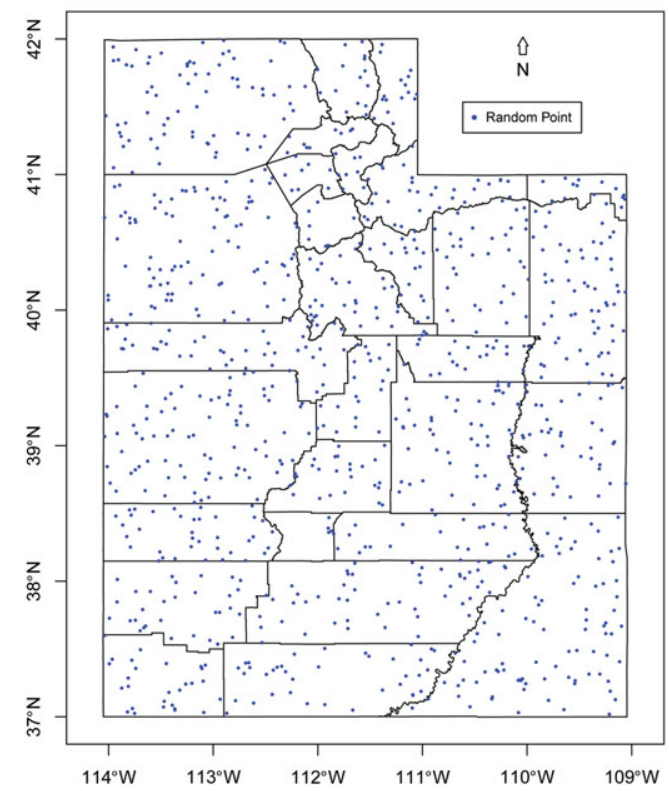

Figure 2. Map of Utah, USA, showing (a) settlement locations colored from older (lighter) to newer (darker), and (b) random point locations. (Color online)

[IQR]: 1856-1878) are from a variety of sources (Barton 1998; Carr 1986; Fruit Heights City, Utah 2016; Jenson 1941; Leigh 1961; Steele 1960; Thompson 1982; Torrey, Utah 2016; Utah Writers' Project 1940; Van Cott 1990; West Point, Utah 2016; White 1994). Settlement locations are determined using Google Earth (2014) and GeoHack (Wikimedia Tool Labs 2013; see Figure 2).

Census Data. Both statewide and individual settlement population data come from decadal United States census data from 1850 to 1950 (United States Census Bureau Administration and Customer Services 2016). These records generally indicate changes in place names, and such changes are cross-referenced for consistency (Carr 1986; Thompson 1982; Utah Writers' Project 1940). Annual population estimates between censuses are linearly interpolated using the decadal census data. Linear interpolation is also used for missing decadal census data.

\section{Suitability Proxy Selection}

Early Euro-American settler-colonists were agrarian focused (Abruzzi 1987; Arrington and May 1975; Dyal 1989; Jackson 1978; Smith
2015). As such, evaluations of suitability are based on agricultural suitability. Other factors also influenced the settlement decisions of early Euro-Americans, including distance to major transportation corridors and established settlements, strategic locations, ease of irrigation, slope, area of cultivatable land, and the presence of locally available resources (e.g., timber, mineral resources, grazing; Meinig 1965; Ricks 1930). While these other factors likely affected the settlement decisions of early Euro-American settler-colonists, agricultural suitability was primary (Abruzzi 1987; Arrington and May 1975; Brown et al. 1994; Dyal 1989; Meinig 1965; Malouf and Findlay 1986; Ricks 1930).

As a proxy for agricultural suitability, we draw on the work of Ramankutty and colleagues (2002) to generate two local measures: Moisture Index (MI) and Probability of Cultivation (S). Given the arid nature of the American West, we assume water is the most limited resource necessary for agriculture. As such, MI alone may provide a reliable proxy for suitability. Because other factors such as soil chemistry and growing season also affect agricultural suitability, we include a second proxy for agricultural suitability, the Probability of Cultivation (S). 
Moisture Index. The Moisture Index (MI) is calculated as:

$$
M I=\frac{E T_{a c t}}{P E T}
$$

where $\mathrm{ET}_{\text {act }}$ is the actual evapotranspiration and PET is the potential evapotranspiration. The normalization results in a zero to one index representing the abundance of water available to plants (Ramankutty et al. 2002).

We calculated MI for Utah using a raster of annual actual $\left(E T_{a c t}\right)$ and potential (PET) evapotranspiration data from 2000 to 2013 derived from the MODIS 16 instrumentation (Mu et al. 2011, 2013; Numerical Terradynamic Simulation Group 2013). Using ArcMap 10.3.1 Raster Calculator (Spatial Analyst), we created a raster dataset with a resolution of $2.6 \mathrm{~km}^{2}$ containing values representative of the average Moisture Index for Utah over the 14-year period (ESRI 2015). These are remotely sensed data and as such represent reflective surfaces (e.g., urban areas, lakes, and the Utah Salt Flats) as null values in the dataset. Areas of null values that are not bodies of water are interpolated using Inverse Distance Weighting (3D Analyst) in ArcMap 10.3.1(ESRI 2015).

Suitability. The Probability of Cultivation (S) is calculated as a normalized product of growing degree days (GDD), available moisture (MI), soil carbon $\left(\mathrm{C}_{\text {soil }}\right)$, and soil $\mathrm{pH}\left(\mathrm{pH}_{\text {soil }}\right)$. The equation is divided into two components:

$$
S=\mathrm{S}_{\text {clim }} * S_{\text {soil }}
$$

where

$$
\mathrm{S}_{\text {clim }}=f_{1}(\mathrm{GDD}) f_{2}(\mathrm{MI})
$$

and

$$
S_{\text {soil }}=g_{1}\left(C_{\text {soil }}\right) g_{2}\left(p H_{\text {soil }}\right) .
$$

Climate suitability $\left(\mathrm{S}_{\text {clim }}\right)$ is calculated as a normalized probability density function of cropland area to growing degree days $\left(f_{I}[\mathrm{GDD}]\right)$ and a probability density function of cropland area to Moisture Index $\left(f_{2}[\mathrm{MI}]\right.$; Ramankutty et al. 2002). Soil suitability $\left(\mathrm{S}_{\text {soil }}\right)$ is calculated using a sigmoidal function of the soil carbon density and soil acidity/alkalinity. The optimum soil carbon range is from 4 to $8 \mathrm{~kg}$ of $\mathrm{C} / \mathrm{m}^{2}$ and the optimum range of soil $\mathrm{pH}$ is from 6 to 7 (Ramankutty et al. 2002). The resulting $S$ value varies from zero to one indicating the probability of agricultural cultivation on a global scale.

To implement the equation for $\mathrm{S}$, growing degree days (GDD) are calculated using the USPEST degree-day mapping calculator and PRISM climate maps with a minimum temperature threshold of $50^{\circ} \mathrm{F}$ (Coop 2014; Daly et al. 2002; Willmott and Robeson 1995). Moisture Index data are calculated as described above. To calculate overall climate suitability $\left(S_{\text {clim }}\right)$, existing functions are fit to the resulting raster datasets of growing degree days and Moisture Index and combined in ArcMap 10.3.1 using the Raster Calculator (Spatial Analyst) to create a climate suitability $\left(S_{\text {clim }}\right)$ raster dataset with a resolution of $2.6 \mathrm{~km}^{2}$ (ESRI 2015; Ramankutty et al. 2002). To calculate soil suitability, we apply the functions provided by Ramankutty and colleagues (2002) to soil data derived from the SSURGO soil dataset compiled using NRCS Soil Data Viewer 6.1 to create thematic maps of average soil $\mathrm{pH}$ within the top and average carbon density within the top $30 \mathrm{~cm}$ (Soil Survey Staff, Natural Resources Conservation Service, United States Department of Agriculture 2015; United States Department of Agriculture, Natural Resource Conservation Service Soils 2015). Missing values in the SSURGO soil dataset result in datasets that use soil acidity/alkalinity to have null values in some areas of the state (Soil Survey Staff, Natural Resources Conservation Service, United States Department of Agriculture 2015). The resulting raster datasets of soil acidity/alkalinity and carbon density are combined in ArcMap 10.3.1 using the Raster Calculator (Spatial Analyst) to create a soil suitability $\left(S_{\text {soil }}\right)$ raster dataset with a resolution of $9.2 \mathrm{~km}^{2}$ (ESRI 2015). The climate suitability raster dataset and soil suitability raster dataset are combined in ArcMap 10.3.1 using the Raster Calculator (Spatial Analyst) resulting in an $S$ raster dataset with a resolution of $9.2 \mathrm{~km}^{2}$ (ESRI 2015).

The methods above result in two statewide raster datasets: The Moisture Index and the Probability of Cultivation. Because of missing values in the SSURGO data, some regions of the state lack Probability of Cultivation (S) values. These 

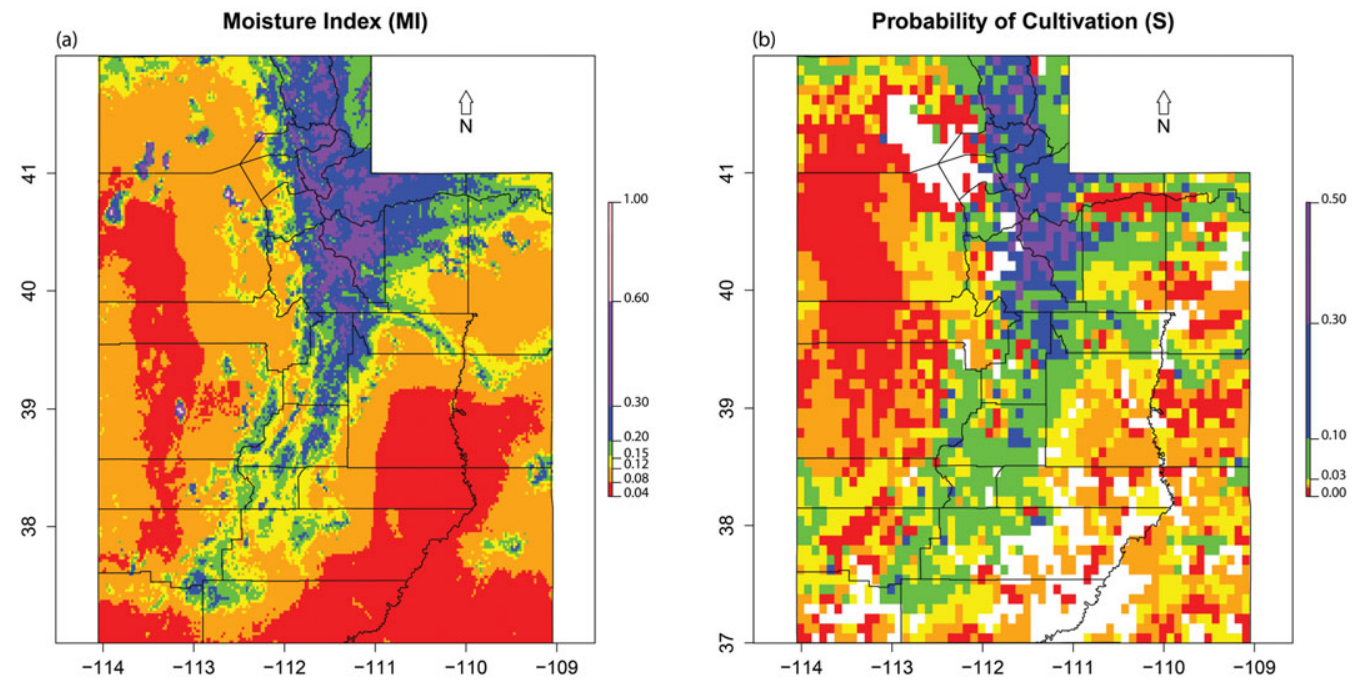

Figure 3. Map of Utah, USA, showing (a) the Moisture Index (MI) and (b) Probability of Cultivation (S). (Color online)

data are shown in Figure 3 and are available on the Harvard Dataverse (Yaworsky 2016a, 2016b).

We extract MI and S values using ArcMap 10.3.1 with the Extract Multi Values to Points (Spatial Analyst) for settlements by averaging raster values within a $5 \mathrm{~km}$ radius around each settlement as a proxy for each settlement's suitability (ESRI 2015). We do not account for fluctuations in past $\mathrm{S}$ and MI values, as we assume that relative $\mathrm{MI}$ and $\mathrm{S}$ values between locations remained constant. That is, if suitability declined by an order of magnitude in one area, it also declined by a similar magnitude in other areas with the relative rankings between habitats remaining constant (following Codding and Jones 2013).

Random Suitability Values. To determine if the settlement suitability values differed from background values, we generate 1,000 random points (see Figure 2) in ArcMap 10.3.1 using the Create Random Points function in the Data Management toolbox. We then extract $\mathrm{S}$ and MI values using Extract Multi Values to Points (Spatial Analyst) (ESRI 2015).

\section{Statistical Analysis}

Suitability. To calculate the overall agricultural suitability experienced annually by farmers, we compute median MI and S values across all occupied settlements. We report the median and the interquartile range (25\%-75\% of cases) for both the observed annual values and the random values.

Null Distribution Test. To determine if the observed settlement data are significantly different than random data, settlement $\mathrm{MI}$ and $\mathrm{S}$ values are compared with values of the random points. This serves as a test of a null model, where S or MI values do not guide settlement decisions. We use a Two-Sample KolmogorovSmirnov (KS) test and examine the result graphically as an empirical cumulative density function.

Spatial Autocorrelation. Settlement patterns may bias $\mathrm{S}$ and MI values if neighboring settlements are more likely to be settled at similar times. To test for such spatial autocorrelation, we rely on the Global (Paradis et al. 2016) and the Local Moran's I (Giraudoux and Giraudoux 2016). Global Moran's I evaluates whether neighboring points across the entire study area have more similar or different settlement dates than would be expected by chance. Local Moran's I performs the same test, but over ranges of distances (or neighborhoods) to determine the spatial scale at which spatial autocorrelation may occur. 
Settlement Date and Suitability. To assess the prediction that the earliest settlements should have higher suitability than later settlements, we examine how suitability (MI and S) varies as a function of settlement founding date using generalized additive models (GAMs). GAMs are nonparametric extensions of generalized linear models (GLMs) that incorporate smooth terms as penalized regression splines selected by a backfitting algorithm (Hastie and Tibshirani 1999; Wood 2012). While this allows the data to "speak for themselves" because the analyst does not need to specify a functional relationship, it can also lead to overfitting. To avoid this problem, we maximize parsimony by limiting degrees of freedom (knots) to the minimum possible for each model. Another benefit of GAMs is that they can control for the effects of spatial autocorrelation (if present, see above) by including paired point coordinates as an additional smoothed term (Wood 2006). For each GAM, we report the $\mathrm{r}^{2}$ value for the whole model, and the estimated degrees of freedom, F value, and $\mathrm{p}$-value for both the settlement founding date and coordinates.

Density Dependence. In order to test the prediction of negative density dependence quantitatively, we examine annual variation in median $\mathrm{S}$ and MI values as a function of the population using generalized additive mixed models (GAMMs; Wood 2006, 2011, 2012). GAMMs are extensions of GAMs that incorporate a generalized additive model component with a linear mixed effect model component, which can be used to include a correlation structure to account for temporal autocorrelation (Wood 2006, 2012). This resolves the problem of non-independence that is often present in time series data. To implement this, we control for a first-order temporal correlation structure (corAR1) and assess the results with an autocorrelation function. Given that the dependent variables (MI and $\mathrm{S}$ ) vary from zero to one, we specify a binomial distribution with a log link and quasi-likelihood estimation. Results report the estimated degrees of freedom of the smoothed term, the $\mathrm{F}$ value, the $\mathrm{r}^{2}$ value, and the p-value. We used the results of the fitted models to examine diachronic patterning in occupied habitat suitability.
Temporal Autocorrelation. In order to evaluate if temporal autocorrelation, the influence of neighboring points on one another, drives the pattern of density dependence, we examine the standardized residuals of the fitted GAMM using the autocorrelation function in $\mathrm{R}$ ( $\mathrm{R}$ Core Team 2015), which determines how similar or different neighboring points are to one another. If temporal autocorrelation is detected, we report the lag (in years) over which neighboring points influence one another. All statistical analyses described above are run in the $\mathrm{R}$ environment ( $\mathrm{R}$ Core Team 2015).

\section{Results}

Of the 100 randomly selected settlements, necessary data are available for 84 . Overall, these 84 occupied settlements have a median Moisture Index (MI) value of 0.19 (IQR: 0.13-0.24) and a median Probability of Cultivation (S) value of 0.04 (IQR: 0.02-0.08). Of the 1,000 random points, 116 are excluded, as they were located in areas with null S and MI values. The remaining 884 points have a median Moisture Index value of 0.10 (IQR: 0.08-0.15) and a median Agricultural Suitability value of 0.022 (IQR: 0.014-0.04).

\section{Does Settlement Suitability Differ from Random?}

A comparison of the observed and random data reveals that Euro-American settlement patterns achieved $\mathrm{S}(D=0.39 ; p<0.0001)$ and $\mathrm{MI}$ $(D=0.46 ; p<0.0001)$ values that are significantly higher than random. As shown in Figure 4, occupied settlement locations are biased toward areas of relatively high suitability, and the median annual suitability experienced by historical populations is higher than random, especially when considering available moisture. This indicates that settlement decisions were purposeful and biased toward higher suitability habitats.

\section{Do Neighboring Settlements Have Similar Founding Dates?}

The Global Moran's I test indicates minor positive spatial autocorrelation of settlement year ( $I=0.06 ; p<0.01)$, indicating that neighboring settlements are more likely to have similar founding dates than would be expected by chance. 


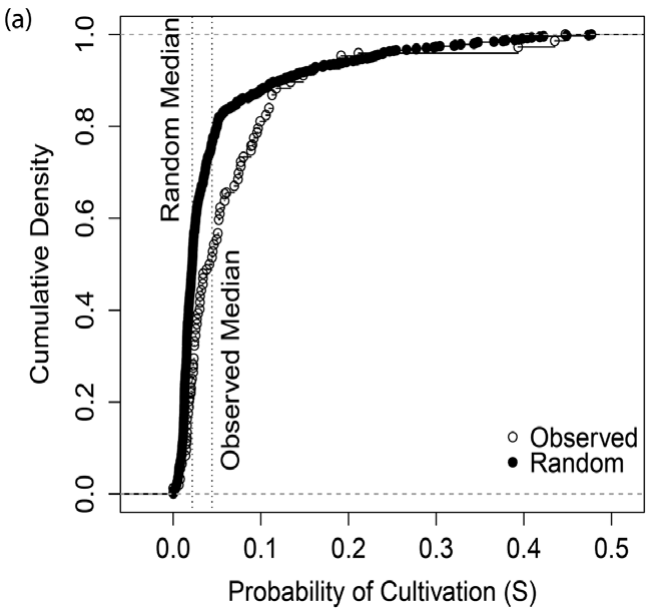

(b)

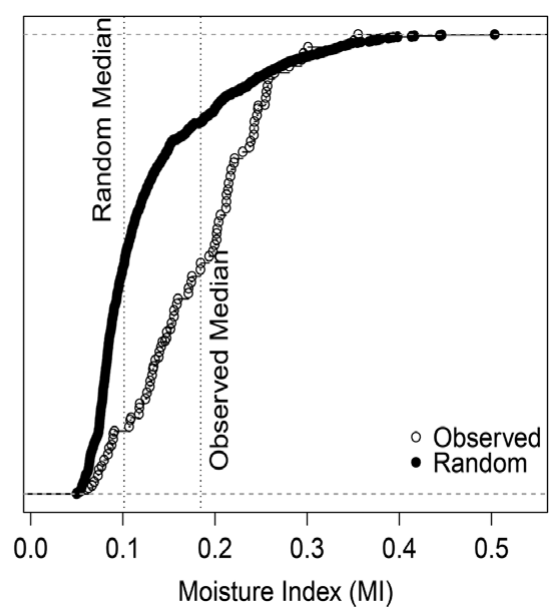

Figure 4. Comparison of the observed (a) Probability of Cultivation (S) and (b) Moisture Index (MI) for occupied habitats to randomly distributed points on the landscape.

The Local Moran's I test reveals that spatial autocorrelation occurs only up to a distance (lag) of $22.5 \mathrm{~km}(I=.27 ; p<0.0001)$. This pattern of spatial autocorrelation disappears at distances greater than $22.5 \mathrm{~km}$. This shows that only settlements within $22.5 \mathrm{~km}$ of one another are more likely to have been settled in similar years than would be expected at random, indicating that the correlations between settlement founding date and suitability may result from spatial autocorrelation. To account for this, we control for the coordinates of each settlement when examining the effect of settlement date on suitability.

\section{Are Earlier Settlements in Higher Suitability Habitats?}

Controlling for spatial autocorrelation, both the Moisture Index and Agricultural Suitability negatively vary with settlement date, revealing that earlier settlements were founded in higher suitability habitats than later settlements. Settlement date is a stronger predictor of $\mathrm{MI}\left(r^{2}=0.67\right.$; year; $e d f=1.7 ; F=8.67 ; p=0.0011$; coordinates: $e d f=4.36 ; \mathrm{F}=27.87 ; p<0.0001)$, than $\mathrm{S}\left(r^{2}\right.$ $=0.15$; year: $e d f=1 ; F=3.34 ; p=0.0713$; coordinates: $e d f=3.74 ; F=3.61 ; p=0.0094)$, with the latter relationship being significant only at the $<0.1$ level. These models show that earlier settlements were established in higher suitability habitats, even when the local effects of spatial autocorrelation are removed, though only the effect of available moisture remains highly significant.

\section{Does the Suitability of Occupied Habitats Decline with Increasing Populations?}

The overall temporal trends reveal a pattern of decreasing habitat suitability coincident with increasing populations across the sampled settlements and the state as a whole (Figure 5). The total population occupying the sampled settlements increases from 1,539 to 280,785 and the overall state population increases from 2,845 to 688,862 over the observation period from 1847 to 1950. Median Agricultural Suitability (S) values decline from a high of 0.10 to 0.03 and median Moisture Index (MI) values decline from a high of 0.22 to 0.17 . This suggests that the prediction of negative density dependence holds across this colonization event.

A quantitative evaluation of these trends confirms the IFD predictions (Figure 6). Median Agricultural Suitability (S) and Moisture Index (MI) values decline significantly with both settlement population size $(\mathrm{S}:$ edf $=1.97 ; F=$ 97; $r^{2}=0.74 ; p<0.0001$; MI: edf $=1.97$; $\left.F=93.34 ; r^{2}=0.73 ; p<0.0001\right)$ and total state population size $(\mathrm{S}: e d f=1.96 ; F=56.36$; $r^{2}=0.91 ; p<0.0001 ;$ MI: $e d f=1.96 ; F=$ $\left.54.58 ; r^{2}=0.91 ; p<0.0001\right)$. Note that the subtle increase in $\mathrm{S}$ and $\mathrm{MI}$ at higher populations, 

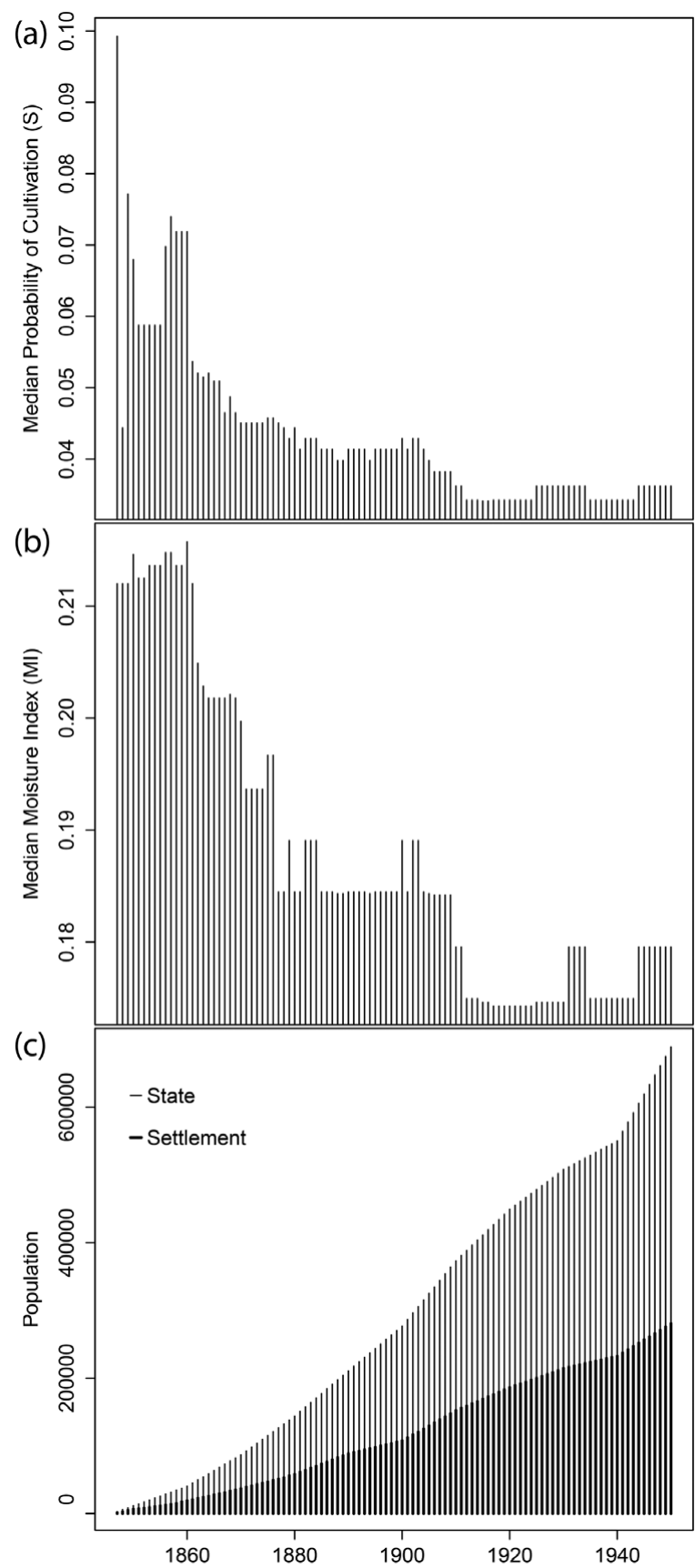

Figure 5. Summary of time-series data illustrating (a) the changes in the overall Probability of Cultivation (S) of occupied habitats, and (b) the overall Moisture Index (MI) of occupied habitats and (c) the trends in statewide and sampled settlement populations.

around 175,000 (settlement) and 500,000 (state), is not statistically meaningful as the confidence interval has both positive and negative slope. The results suggest that populations adaptively respond to increasing competition by moving into lower-suitability habitats.

An examination of the standardized model residuals reveals that only minor temporal auto- 
(a)

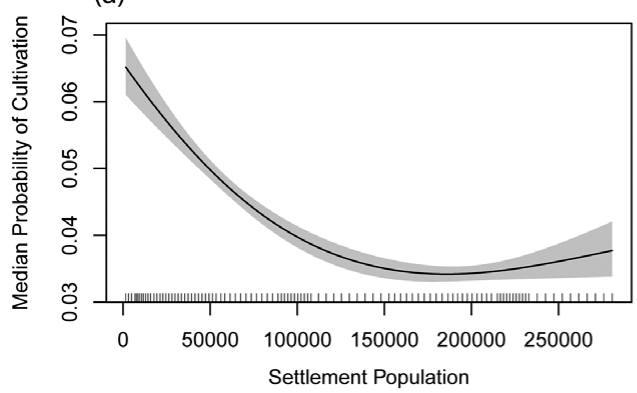

(c)

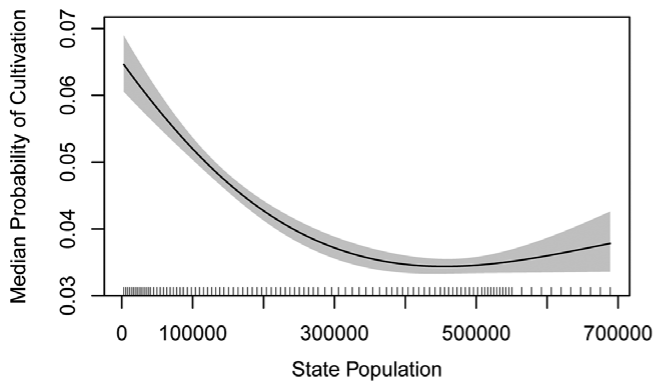

(b)

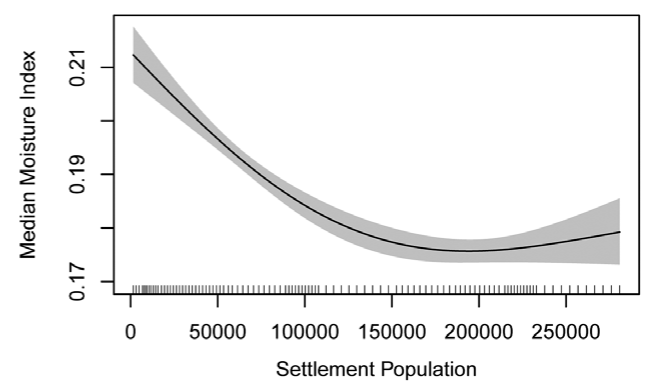

(d)

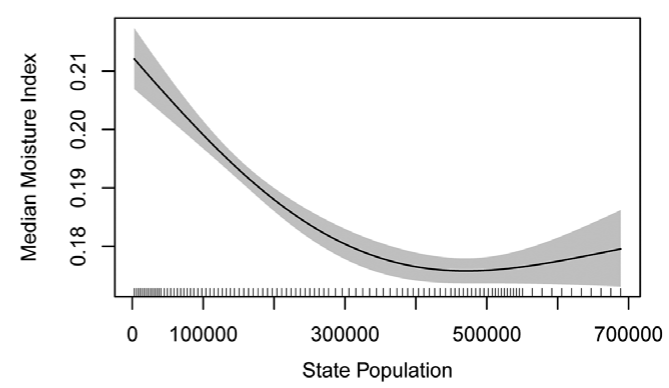

Figure 6. Results of generalized additive mixed models examining variation in annual median Probability of Cultivation (S) and Moisture Index (MI) values for occupied settlements as a function of the total settlement sample population (a and b) and total state population (c and d). Note that the subtle increase in S and MI at higher populations, around $\mathbf{1 7 5 , 0 0 0}$ (settlement) and 500,000 (state), is not statistically meaningful as the confidence interval has both positive and negative slope.

correlation (up to a three-year lag) remains in the models examining $\mathrm{S}$ and $\mathrm{MI}$ as a function of settlement populations, indicating that variation in annual trends over a three-year moving window are partially explained by the influence of neighboring point values. However, no temporal autocorrelation remains in the models examining $\mathrm{S}$ and $\mathrm{MI}$ as a function of the statewide population.

Statewide population also explains much more of the deviance in S and MI, suggesting that state-rather than sample settlement-level competition drives variation in suitability. The shape of this model fit suggests that the effects of agricultural populations on habitat suitability follow an exponentially decreasing function: human populations deplete habitats more quickly than predicted by the basic mathematical model (see Figure 1; Greene and Stamps 2001). This may indicate a pattern of "despotic" rather than "free" distribution (Fretwell and Lucas 1969).

\section{Discussion}

Our results show that, as population grew, Euro-American settler-colonists began to occupy lower-suitability habitats. These findings suggest that individual settlement decisions were aimed at maximizing agricultural productivity. As a result, increasing competition within habitats led individuals to settle in locations with lower suitability to maintain equitable yields. These findings are consistent with IFD predictions, but as is common with archaeological and historical data, it is impossible to know if the observed pattern is a direct result of the decisions of Euro-American settlers-colonists to move elsewhere when the suitability of one habitat declined to that of the next most suitable habitat. However, our demonstration of the negative relationship between population and habitat suitability is consistent with predictions from IFD/IDD. These results have important implications for understanding this particular historical settlement event, future archaeological applications of the IFD model, 
and the utility of such models for understanding human behavior in general.

\section{Insights into the Euro-American Settlement of Utah}

While historians have offered many proximate explanations for the settlement of Utah (Abruzzi 1987; Jackson 1978; Ricks 1930; Smith 2015), none link the dispersal to a broader theory of human behavior. The empirical evidence provided here is consistent with the conclusion that Euro-American settlers based settlement decisions on maximizing their agricultural output within demographic constraints. This is not surprising given the agricultural basis for this settler-colonist economy, and the necessity to provide not only for self and family, but also to the local theocratic government through tithing (Abruzzi 1987; Arrington and May 1975; Arrington 1954; Dyal 1989).

First, considering the need to provide for self and family, having a reliable income was necessary for a frontier population that experienced relatively high mortality resulting in riskaverse reproductive decisions (Jones and Bliege Bird 2014). Moreover, beyond providing for existing family, male-headed households within this polygynous society may also have been motivated to excel economically in order to gain additional wives (Heath and Hadley 1998).

Second, considering the need to provide for the local theocratic government, settlers needed to be sufficiently productive to generate a significant surplus (Abruzzi 1987; Arrington and May 1975). This may have made settlers particularly sensitive to demography-driven declines in suitability, causing the rapid expansion into lower-suitability habitats. Alternatively, while we assume that the "free" condition was upheld in this context, our results (Figure 6) suggest that individuals expanded into lower-suitability habitats more rapidly than would be expected by the standard IFD model (compare Figure 1 and Figure 6; Fretwell and Lucas 1969; though see Bell and Winterhalder 2014). The rapid expansion into lower-suitability habitats may be a product of centralized leadership decisions that directed settlement. This provides an empirical result that may describe generally what results from a centrally directed frontier settlement strategy (i.e., a decelerating rather than an accelerating function), a finding that may prove useful for interpreting archaeological dispersions (see below). These trends also may have been influenced by regional knowledge obtained by Mormon scouting parties, presenting potentially interesting questions pertaining to the importance of the IFD model's assumption of complete information.

\section{Implications for Archaeological Applications of the IFD Model}

Our use of historical data to evaluate IFD predictions has three significant implications for archaeological tests of the IFD model. Specifically, this application provides (1) a validation of model assumptions, (2) novel proxies that archaeological case studies can use, and (3) insights into the empirical record that results from a rapidly dispersing population.

First, the findings support the main IFD prediction that habitat choice negatively covaries with population density over relatively long spans of time. While we measure changes in median overall suitability, not changes within each habitat, these results support the model assumption of negative density dependence and provide a justification for future archaeological applications to use aggregate estimates of population density and suitability. Second, our results help to validate two measures of agricultural suitability: The Moisture Index (MI) and the Probability of Cultivation (S). These two proxies can be used to assess the ideal distribution of settler-colonists worldwide (e.g., Timpson et al. 2014; Shennan et al. 2013). Finally, because these findings are linked to a detailed historical record that reveals the despotic structure underlying this dispersion, our empirical results provide an expectation for what such events may look like in the archaeological record, though additional modeling and empirical work are needed to validate this hypothesis.

\section{Conclusion}

Overall, these findings highlight the value of historical data for evaluating archaeologically applicable models from behavioral ecology. Implementation of the IFD model to date 
relies either on archaeologically derived, coarsegrained diachronic data, or ethnographically derived, fine-grained synchronic data. The former allows for long-term diachronic assessments of settlement patterns, but generally relies on untested proxies of population and suitability. The latter has the benefit of fine-grained population data and validated proxies of suitability, but lacks diachronic data to assess settlement decisions through time (e.g., Moritz et al. 2014). The explanatory power of the IFD model demonstrated here uses historically derived data that are both fine-grained (annual scale) and diachronic (ca. 100 years), allowing for the observation of long-term aggregate trends of individual decision making. The intermediate level of resolution and temporal scale of historical data, relative to archaeologically derived and ethnographically derived data, allows us to assess suitability proxies and test IFD predictions concerning the relationship between population density and habitat suitability.

The negative relationship between population density and habitat suitability found in the historical settlement of Utah is consistent with IFD predictions, suggesting that early EuroAmerican settlers of Utah attempted to maximize agricultural productivity. These insights into the settlement dynamics that structured the historical colonization of Utah result from our use of a general theory of behavior (see Bird and O'Connell 2006; Codding and Bird 2015; O'Connell 1995). The behavioral ecological approach simplifies real-world variation into the necessary components required to explain a particular phenomenon. This is one of the major benefits of adopting a formal theoretical approach guided by behavioral ecology. Our findings validate assumptions of the IFD model with the use of historical data, thus archaeologists can confidently expand archaeological application of IFD models to the investigation of prehistoric colonization events. The IFD model is a simple and quantitative approach, with the potential to address colonization and migration events throughout human history.

Acknowledgments. Many thanks are due to Isaac Hart for his assistance in developing suitability data for the State of Utah and to the University of Utah Archaeological Center, specifically Joan Brenner-Coltrain, Kate Magargal, Erik Martin, and Blake Vernon, for support and substantive comments on previous versions of this manuscript. We are also grateful for the detailed comments provided by three anonymous reviewers and Robert Kelly, who helped us improve this paper.

Data Availability Statement. The Moisture Index (MI) and Probability of Cultivation (S) data are available on the Harvard Dataverse (Yaworsky 2016a, 2016b). Supplemental material, including settlement data, population data, and suitability scores are available on the Harvard Dataverse (Yaworsky 2017).

\section{References Cited}

Abruzzi, William S.

1987 Ecological Stability and Community Diversity during Mormon Colonization of the Little Colorado River Basin. Human Ecology 15(3):317-338.

Allen, Douglas W.

1991 Homesteading and Property Rights; Or, "How the West Was Really Won." The Journal of Law and Economics 34(1):1-23.

Anderson, Nels

1942 Desert Saints: The Mormon Frontier in Utah. The University of Chicago Press, Chicago.

Arrington, Leonard J.

1954 The Mormon Tithing House: A Frontier Business Institution. The Business History Review 28(1):24-58.

Arrington, Leonard J., and Dean May

1975 "A Different Mode of Life": Irrigation and Society in Nineteenth-Century Utah. Agricultural History 49(1):3-20.

Barton, John D.

1998 A History of Duchesne County. Utah Centennial County History Series. Salt Lake, Utah: [Duchesne, Utah]: Utah State Historical Society, Duchesne County Commission.

Bell, Adrian V, Thomas E Currie, Geoffrey Irwin, and Christopher Bradbury

2015 Driving Factors in the Colonization of Oceania: Developing Island-Level Statistical Models to Test Competing Hypotheses. American Antiquity 80(2):397407.

Bell, Adrian Viliami, and Bruce Winterhalder

2014 The Population Ecology of Despotism: Concessions and Migration Between Central and Peripheral Habitats. Human Nature 25(1):121-135.

Bird, Douglas W., and James F. O'Connell

2006 Behavioral Ecology and Archaeology. Journal of Archaeological Research 14(2):143-188.

Blackhawk, Ned

2006 Violence over the Land: Indians and Empires in the Early American West. Harvard University Press, Cambridge, Massachusetts. Electronic document, http://search.ebscohost.com/login.aspx?direct= true $\&$ scope $=$ site $\& d b=$ nlebk $\& d b=$ nlabk $\& A N=282411$, accessed February 13, 2017.

Brown, S., D. Cannon, and R. Jackson (editors)

1994 Historical Atlas of Mormonism. Simon and Schuster, New York.

Carr, Stephen L

1986 The Historical Guide to Utah Ghost Towns. Western Epics, Salt Lake City, Utah. 
Codding, Brian F., and Douglas W. Bird

2015 Behavioral Ecology and the Future of Archaeological Science. Journal of Archaeological Science 56: 9-20.

Codding, Brian F., and Terry L. Jones

2013 Environmental Productivity Predicts Migration, Demographic, and Linguistic Patterns in Prehistoric California. Proceedings of the National Academy of Sciences of the United States of America 110(36):1456914573.

Coop, Len

2014 Documentation - US Degree-Day Mapping Calculator. Electronic document, http://uspest.org/wea/ mapmkrdoc.html, accessed August 15, 2014.

Cuch, Forrest S.

2000 History of Utah's American Indians. Utah State University Press, Logan.

Daly, Christopher, Wayne P. Gibson, George H. Taylor, Gregory L. Johnson, and Phillip Pasteris

2002 A Knowledge-Based Approach to the Statistical Mapping of Climate. Climate Research 22(2):99-113.

Dyal, Donald $\mathrm{H}$.

1989 Mormon Pursuit of the Agrarian Ideal. Agricultural ESRI History 63(4):19-35.

2015 ArcGIS Desktop: Release. Environmental Systems Research Institute, Redlands, California.

Farmer, Jared

2008 On Zion's Mount: Mormons, Indians, and the American Landscape. Harvard University Press, Cambridge, Massachusetts. Electronic document, http://search.ebscohost.com/login.aspx?direct= true $\&$ scope $=$ site $\& d b=$ nlebk $\& d b=$ nlabk $\& A N=282481$, accessed February 13, 2017.

Fretwell, Stephen Dewitt, and Henry L. Lucas

1969 On Territorial Behavior and Other Factors Influencing Habitat Distribution in Birds. Acta Biotheoretica 19(1):37-44.

Fruit Heights City, Utah

2016 Fruit Heights City Website. Electronic document, http://www.fruitheightscity.com/index.aspx?nid=106, accessed March 9, 2016.

Galle, Jillian

2010 Costly Signaling and Gendered Social Strategies Among Slaves in the Eighteenth-Century Chesapeake: An Archaeological Perspective. American Antiquity 75(1):19-43.

Giovas, Christina M., and Scott M. Fitzpatrick

2014 Prehistoric Migration in the Caribbean: Past Perspectives, New Models and the Ideal Free Distribution of West Indian Colonization. World Archaeology 46(4):569-589.

Giraudoux, Patrick

2016 Package "pgirmess." Data Analysis In ecology. -R Package Ver 1(4). Electronic document, http://202.90.158.4/pub/pub/R/web/packages/ pgirmess/pgirmess.pdf, accessed February 11, 2017.

Glover, Susan M.

2009 Propaganda, Public Information, and Prospecting: Explaining the Irrational Exuberance of Central Place Foragers during a Late Nineteenth Century Colorado Silver Rush. Human Ecology 37(5):519-531.

Google Earth

2014 Google Inc.

Greene, Correigh M., and Judy A. Stamps

2001 Habitat Selection at Low Population Densities. Ecology 82(8):2091-2100.
Hastie, Trevor, and Robert Tibshirani

1999 Generalized Additive Models. Chapman \& Hall/CRC, Boca Raton, Florida.

Heath, Kathleen Marie, and Craig Hadley

1998 Dichotomous Male Reproductive Strategies in a Polygynous Human Society: Mating versus Parental Effort. Current Anthropology 39(3):369_ 374.

Hildebrandt, William, Kelly McGuire, and Jerome King

2016 Prehistory of Nevada's Northern Tier: Archaeological Investigations along the Ruby Pipeline. American Museum of Natural History Anthropological Papers, Number 101. American Museum of Natural History, New York, http://digitallibrary.amnh.org/bitstream/ handle/2246/6640/AP101.pdf? sequence $=2 \&$ isAllowed=y, accessed August 15, 2016

Jackson, Richard H

1978 Mormon Perception and Settlement. Annals of the Association of American Geographers 68(3):317334

Jazwa, Christopher S., Douglas J. Kennett, and Bruce Winterhalde

2013 The Ideal Free Distribution and Settlement History at Old Ranch Canyon, Santa Rosa Island, California. In California's Channel Islands: The Archaeology of Human-Environment Interactions, edited by Christopher S. Jazwa and Jennifer E. Perry, pp. 75-96. University of Utah Press, Salt Lake City.

Jazwa, Christopher S., Douglas J. Kennett, and Bruce Winterhalder

2016 A Test of Ideal Free Distribution Predictions Using Targeted Survey and Excavation on California's Northern Channel Islands. Journal of Archaeological Method and Theory 23(4):1242-1284.

Jenson, Andrew

1941 Encyclopedic History of the Church of Jesus Christ of Latter-day Saints. Deseret News Publishing Company. Electronic document, http://contentdm.lib.byu. edu/cdm/ref/collection/BYUIBooks/id/2694, accessed April 14, 2016

Jones, James Holland, and Rebecca Bliege Bird

2014 The Marginal Valuation of Fertility. Evolution and Human Behavior 35(1):65-71.

Kennett, Douglas J.

2005 The Island Chumash: Behavioral Ecology of a Maritime Society. University of California Press, Berkeley.

Leigh, Rufus

1961500 Utah Place Names. Deseret New Press, Salt Lake City, Utah.

Lindell, Jennifer

2011 Mormons and Native Americans in the Antebellum West. Master's thesis, Department of History, San Diego State University. Electronic document, http://scholarworks.calstate.edu/handle/10211. 10/1445, accessed February 3, 2017.

Malouf, Carling I., and John M. Findlay

1986 Euro-American Impact before 1870. In Great Basin, edited by Warren L. d' Azevedo, pp. 499-516. Handbook of North American Indians, Vol. 11, William C. Sturtevant, general editor, Smithsonian Institution, Washington, DC.

Meinig, Donald W.

1965 The Mormon Culture Region: Strategies and Patterns in the Geography of the American West, 18471964. Annals of the Association of American Geographers 55(2):191-219. 
Moritz, Mark, Ian M. Hamilton, Yu-Jen Chen, and Paul Scholte

2014 Mobile Pastoralists in the Logone Floodplain Distribute Themselves in an Ideal Free Distribution. Current Anthropology 55(1):115-122.

Moritz, Mark, Ian M. Hamilton, Andrew J. Yoak, Paul Scholte, Jeff Cronley, Paul Maddock, and Hongyang Pi

2015 Simple Movement Rules Result in Ideal Free Distribution of Mobile Pastoralists. Ecological Modelling 305:54-63.

$\mathrm{Mu}$, Qiaozhen, Maosheng Zhao, and Steven W. Running

2011 Improvements to a MODIS Global Terrestrial Evapotranspiration Algorithm. Remote Sensing of Environment 115(8): 1781-1800.

2013 MODIS Global Terrestrial Evapotranspiration (ET) Product (NASA MOD16A2/A3). Algorithm Theoretical Basis Document, Collection 5. Electronic document, http://www.ntsg.umt.edu/sites/ntsg.umt.edu/ files/MOD16_ATBD.pdf, accessed July 3, 2016.

Neiman, Fraser D.

2008 The Lost World of Monticello: An Evolutionary Perspective. Journal of Anthropological Research 64(2):161-193.

Numerical Terradynamic Simulation Group

2013 MODIS Global Evapotranspiration Project (MOD16). University of Montana. Electronic document, http://www.ntsg.umt.edu/project/mod16, accessed December 12, 2015

O'Connell, James F.

1995 Ethnoarchaeology Needs a General Theory of Behavior. Journal of Archaeological Research 3(3):205-255.

O'Connell, James F., and Jim Allen

2012 The Restaurant at the End of the Universe: Modelling the Colonisation of Sahul. Australian Archaeology (74):5-17.

Paradis, Emmanuel, Simon Blomberg, Ben Bolker, Julien Claude, Hoa Sien Cuong, Richard Desper, Gilles Didier, Benoit Durand, Julien Dutheil, RJ Ewing, Olivier Gascuel, Christoph Heibl, Anthony Ives, Bradley Jones, Daniel Lawson, Vincent Lefort, Pierre Legendre, Jim Lemon, Rosemary McCloskey, Johan Nylander, Rainer Opgen-Rhein, Andrei-Alin Popescu, Manuela RoyerCarenzi, Klaus Schliep, Korbinian Strimmer, and Damien de Vienne

2016 Package "Ape." Analyses of Phylogenetics and Evolution, Version: 2-4.

Prufer, Keith M., Amy E. Thompson, Clayton R. Meredith, Brendan J. Culleton, Jillian M. Jordan, Claire E. Ebert, Bruce Winterhalder, and Douglas J. Kennett

2017 The Classic Period Maya Transition from an Ideal Free to an Ideal Despotic Settlement System at the Polity of Uxbenká. Journal of Anthropological Archaeology 45:53-68

$\mathrm{R}$ Core Team

2015 R: A Language and Environment for Statistical Computing. R Foundation for Statistical Computing, Vienna, Austria. Electronic document, http:// www.R-project.org/.

Ramankutty, Navin, Jonathan A. Foley, John Norman, and Kevin McSweeney

2002 The Global Distribution of Cultivable Lands: Current Patterns and Sensitivity to Possible Climate Change. Global Ecology and Biogeography 11(5):377392.
Ramankutty, Navin, Jonathan A. Foley, John Norman, and Kevin McSweeney

2002 The Global Distribution of Cultivable Lands: Current Patterns and Sensitivity to Possible Climate Change. Global Ecology and Biogeography 11(5):377392.

Ricks, Joel E.

1930 Forms and Methods of Early Mormon Settlement in Utah and the Surrounding Region, 1847 to 1877 . PhD dissertation, Department of History, The University of Chicago, Chicago.

Scarlett, Timothy James

2006 Globalizing Flowscapes and the Historical Archaeology of the Mormon Domain. International Journal of Historical Archaeology 10(2):109-134.

Scarlett, Timothy James, Robert J. Speakman, and Michael D. Glascock

2007 Pottery in the Mormon Economy: An Historical, Archaeological, and Archaeometric Study. Historical Archaeology 41(4):72-97.

Schwindt, Dylan M., R. Kyle Bocinsky, Scott G. Ortman, Donna M. Glowacki, Mark D. Varien, and Timothy A. Kohler

2016 The Social Consequences of Climate Change in the Central Mesa Verde Region. American Antiquity 81(1): 74-96.

Shennan, Stephen, Sean S. Downey, Adrian Timpson, Kevan Edinborough, Sue Colledge, Tim Kerig, Katie Manning, and Mark G. Thomas

2013 Regional Population Collapse Followed Initial Agriculture Booms in Mid-Holocene Europe. Nature Communications 4:2486.

Smaby, Beverly P.

1975 The Mormons and the Indians: Conflicting Ecological Systems in the Great Basin. American Studies 16(1):35-48

Smallwood, Ashley M.

2012 Clovis Technology and Settlement in the American Southeast: Using Biface Analysis to Evaluate Dispersal Models. American Antiquity 77(4):689-713.

Smith, Samuel A.

2015 The Cities of Zion? Mormon and Non-Mormon Town Plans in the U.S. Mountain West, 1847-1930. Journal of Historical Geography 50:1-13.

Soil Survey Staff, Natural Resources Conservation Service, United States Department of Agriculture

2015 Web Soil Survey. United States Department of Agriculture. Electronic document, https://websoilsurvey.sc. egov.usda.gov/App/HomePage.htm, accessed December 12,2015 .

Steele, Raymond Duane

1960 Goshen Valley History. Self-published. Available at Marriott Library, University of Utah.

Thompson, George A.

1982 Some Dreams Die: Utah's Ghost Towns and Lost Treasures. 1st ed. Dream Garden Press, Salt Lake City, Utah.

Timpson, Adrian, Sue Colledge, Enrico Crema, Kevan Edinborough, Tim Kerig, Katie Manning, Mark G. Thomas, and Stephen Shennan

2014 Reconstructing Regional Population Fluctuations in the European Neolithic Using Radiocarbon Dates: A New Case-Study Using an Improved Method. Journal of Archaeological Science 52:549 557. 
Tinbergen, Niko

1963 On Aims and Methods in Ethology. Zeitschrift Für Tierpsychologie 20:410-433.

Torrey, Utah

2016 Torrey City Website. Electronic document, http:// www.torreyutah.gov/, accessed August 15, 2016.

United States Census Bureau Administration and Customer Services

2016 US Census Bureau Publications - Census of Population and Housing. Electronic document, http://www. census.gov/prod/www/decennial.html, accessed March 9, 2016.

United States Department of Agriculture, Natural Resource Conservation Service Soils

2015 Soil Data Viewer. Natural Resources Conservation Service. Electronic document, http://www.nrcs. usda.gov/wps/portal/nrcs/detail/soils/survey/geo/ ?cid=nrcs142p2_053619, accessed March 10, 2016.

Utah Writers' Project

1940 Origins of Utah Place Names: Comp. and Written by Utah Writers' Project, Work Projects Administration. 3rd ed. State Department of Public Instruction, Salt Lake City, Utah.

Van Cott, John W.

1990 Utah Place Names: A Comprehensive Guide to the Origins of Geographic Names: A Compilation. University of Utah Press, Salt Lake City, Utah.

West Point, Utah

2016 West Point City Website. Electronic document, http: //www.westpointcity.org, accessed August 15, 2016.

White, Marilyn Curtis

1994 Keetley, Utah: The Birth and Death of a Small Town. Utah Historical Quarterly 62(3):246-260.

Wikimedia Tool Labs

2013 GeoHack. Electronic document, https://tools. wmflabs.org/geohack/, accessed October 27, 2013.

Willmott, Cort J., and Scott M. Robeson

1995 Climatologically Aided Interpolation (CAI) of
Terrestrial Air Temperature. International Journal of Climatology 15(2):221-229.

Winterhalder, Bruce, Douglas J. Kennett, Mark N. Grote, and Jacob Bartruff

2010 Ideal Free Settlement of California's Northern Channel Islands. Journal of Anthropological Archaeology 29(4):469-490.

Wood, Simon N.

2006 Generalized Additive Models: An Introduction with $R$. Texts in Statistical Science. Chapman \& Hall/CRC, Boca Raton, Florida.

2011 Fast Stable Restricted Maximum Likelihood and Marginal Likelihood Estimation of Semiparametric Generalized Linear Models. Journal of the Royal Statistical Society (B) 73(1):3-36.

2012 Mixed GAM Computation Vehicle with GCV/AIC/ REML Smoothness Estimation. Electronic document, http://cran.r-project.org/web/packages/mgcv, accessed February 6, 2016.

Yaworsky, Peter

2016a A Raster of Remotely Sensed Agricultural Suitability (S) in Utah, U.S.A. Harvard Dataverse. Electronic document, https://doi.org/10.7910/DVN/ T8WBSW, accessed August 26, 2016.

2016b A Raster of Remotely Sensed Agricultural Suitability as a Function of Moisture Index (MI) in Utah, U.S.A. Harvard Dataverse. Electronic document, https://doi.org/doi:10.7910/DVN/9HS0Q7, accessed August 26, 2016.

2017 Supplemental Material for: The Ideal Distribution of Farmers: Explaining the Euro-American Settlement of Utah. Harvard Dataverse. Electronic document, https://doi.org/10.7910/DVN/WWAYYK, accessed August 26, 2016.

Submitted October 18, 2016; Revised May 27, 2017;

Accepted June 9, 2017 